\title{
An Analysis of the Present Situation of the futsal Football in Ganzhou City
}

\author{
Yu-Jing WANG \\ Jiangxi Normal University College of Physical Education \\ Jiang Xi, China \\ E-mail:976151175@qq.com
}

\author{
Bin XIE \\ Jiangxi Normal University College of Physical Education \\ Jiang Xi, China \\ E-mail: www.xiebin66@163.com
}

\begin{abstract}
The face of the five-a-side football this emerging movement, Ganzhou City, the economy is lagging behind, the level of the coastal cities and the mainland is relatively backward. In the context of the five-a-side soccer soccer development in China, the state and society are paying more and more attention to the development level of the five-a-side soccer and the present situation and the present situation are increasing and expanding. The author adopt the methods of literature, questionnaire, expert interview and data statistics, To Ganzhou urban futsal football to carry out the status quo investigation and analysis of the status quo. And the possible existence of capital investment, the enthusiasm of the masses or the lack of facilities such as facilities and other aspects of the study of Ganzhou City, the situation of five-person football to carry out the analysis of the reasons for the existence of the proposed solution to the problem. Which provides a theoretical basis and corresponding reference for the future development of the five - person football in Ganzhou city.
\end{abstract}

\section{Keywords-Ganzhou City; Futsal football; Current Development; Research analysis}

\section{INTRODUCTION}

In the process of reviewing the literature, the authors found that there are relatively few studies on the status quo of the futsal football in Ganzhou City, Jiangxi Province. So we chose the "futsal football in Ganzhou City to carry out the status quo analysis" as a research topic. For the futsal football to carry out the status quo through the Internet access to understand the development of five-person football research status greatly: Outdoor futsal football, Indoor futsal football in China to carry out the status quo, The status quo of the five-a-side football in colleges and universities and the status quo of the futsal football in various provinces and municipalities and related areas have consistently shown that the development of the futsal soccer soccer in China is getting higher and higher. This article aims to understand the status quo of futsal development in contemporary China based on an analysis of futsal universities in Ganzhou city. In so doing, this research not only attempts to use the case in Ganzhou to portrait the futsal development in contemporary China, but also wants to use the empirical materials to supportcarry out the research on the status quo and analysis of the futsal football in China and the present situation and analysis of universities in various provinces and universities in China, and carry out the research on the present situation of the futsal football in Ganzhou city, and increase the development of the futsal football in Ganzhou city research material.

\section{RESULTS AND ANALYSIS}

\section{A. General Description of the Futsal Football in Ganzhou} City

1) The number of teams in Ganzhou Urban Area Survey of Futsal

Five-man football into Ganzhou city only one year,but still loved by the masses of Ganzhou city. Ganzhou City will also set up the first football theme park, covers an area of about 6081.22 square meters. Zhangjiang football theme park is the only football theme park in Ganzhou City, including four five-a-side soccer field and a seven-man soccer field. After the completion of both to meet the public football to carry out, but also to meet the needs of young people training and competition, for the popular mass soccer play a positive role. In 2015 opened the Ganzhou Football Super League, and every year a variety of themes will be held football game. With the development of five-a-side football in Ganzhou city, ganzhou City, five-team football team strength and the number of entries also increased.

2) The Participation of futsal Football Team in Ganzhou City

The survey shows that $55 \%$ of the total number of participants in the Ganzhou urban penthouse football are college students and office workers between the ages of 20 and 40 because they are more energetic and more interested in other age groups. In the survey, the weekly football, the activities of the time for one and a half hours the proportion of the number of $32 \%$, at least twice a week football accounted for $45 \%$, each time for more than half an hour, this is generally a stable income office workers and have a certain degree of sports spending power. More than twice a week accounted for $23 \%$ of the total, the majority of the student groups, the activities of the larger span of time is not fixed. 


\section{3) Futsal venue Facilities Ganzhou Urban Area}

TABLE I. DISTRIBUTION OF FUTSAL FOOTBALL FIELD IN GANZHOU CITY

\begin{tabular}{lllll}
\hline $\begin{array}{l}\text { Site } \\
\text { distributi } \\
\text { on }\end{array}$ & $\begin{array}{l}\text { Zhanggon } \\
\text { g District }\end{array}$ & $\begin{array}{l}\text { Economic } \\
\text { development Zone }\end{array}$ & $\begin{array}{l}\text { Nankan } \\
\text { g } \\
\text { District }\end{array}$ & $\begin{array}{l}\text { Gan County } \\
\text { Zone }\end{array}$ \\
\hline Quantity & 4 & 3 & 2 & 0 \\
\hline
\end{tabular}

From Table 1, we can see that the venues and facilities are the prerequisites for the development of the futsal football. There are few public football venues in the urban areas of Ganzhou. Many games are organized by the various institutions, and most institutions are not independent of their own venues, they often choose to rent or borrow at all levels of college football, because these are efficient venues, the venue is also more open, Grass quality is also good.

4) Futsal tournament referee situation in Ganzhou Urban Area

For the Ganzhou city futsal football match referee qualifications, referee level survey as follows:

TABLE II. GANZHOU URBAN AREA LAW ENFORCEMENT FUTSAL REFEREES EDUCATION FACT SHEET $(\mathrm{N}=20)$

\begin{tabular}{llll}
\hline $\begin{array}{l}\text { Referee } \\
\text { Education }\end{array}$ & College degree & $\begin{array}{l}\text { Bachelor } \\
\text { degree }\end{array}$ & Master's degree \\
\hline percentage\% & 40 & 55 & 5 \\
\hline
\end{tabular}

TABLE III. GANZHOU CITY FUTSAL REFEREES LEVEL FACT SHEET $(\mathrm{N}=20)$

\begin{tabular}{llll}
\hline Referee Level & & Level one & Level two \\
\hline percentage\% & 5 & & 10 \\
\hline
\end{tabular}

Football referees is an important part of the game of football is the game of law enforcement. Football referee law enforcement level to a certain extent, the relationship between the levels of the game, the level of law enforcement is also an important condition to ensure the smooth conduct of football. Aa shown in Table 2, Ganzhou city futsal football referee education focused on college and undergraduate level, in general, the referee's cultural quality is better. Aa shown in Table 3, Ganzhou city level referees accounted for the total number of $1 / 2$ ratio of $25 \%$, two referees accounted for $50 \%$. Big game is performed by a referee, the remaining events are generally carried out by the two law enforcement referee.

5) Futsal sports management in Ganzhou Urban Area

According to the survey, currently in Ganzhou Urban Area futsal tournament in the management system does not have a specialized institution, sports management is still in a "hybrid style." Construction of specialized management rules and regulations very little management and have not targeted, internal resources are not effectively control and management functions of the positioning is not clear, and even the phenomenon of multi-management. Organizational management plays a variety of roles, For example: the role of the administrative units of the organization for the game, Business match and again role cause of corporate involvement. It is the manager of the game and the intermediary of the game. All personnel involved in futsal tournament, And no standardized and unified registration process, Causing the game management confusion, Ganzhou City futsal tournament at the management level, also need to intensify efforts to rectify, $\mathrm{Re}$ - establish the social image of the futsal football in Ganzhou city.

6) Futsal sports event sponsorship funding situation in Ganzhou Urban Area

TABLE IV. GANZHOU CITY FUTSAL SPORT ACTIVITIES FUNDED STATUS

\begin{tabular}{|c|c|c|c|}
\hline $\begin{array}{l}\text { Financial } \\
\text { sources }\end{array}$ & $\begin{array}{l}\text { At their own } \\
\text { expense }\end{array}$ & $\begin{array}{l}\text { Sponsored } \\
\text { enterprises }\end{array}$ & $\begin{array}{l}\text { Unit } \\
\text { funding }\end{array}$ \\
\hline $\begin{array}{l}\text { Participate in } \\
\text { team }\end{array}$ & 2 & 11 & 3 \\
\hline percentage $\%$ & 13 & 68 & 19 \\
\hline
\end{tabular}

Is shown in Table 4, in most Futsal activity in Ganzhou Urban Area, there is no fixed corporate sponsorship and other sources of funding. There are some players they are interested in the same combination of interest to form a team to pay the form of membership to maintain the team's various activities. A small part of the football tournament has been well-known corporate sponsorship and carried out, China's 1995 enactment of the "Sports Law" Article 42 provides: The state encourages enterprises, institutions and social groups self-financing the development of sports, Encourage organizations and individuals to donate to and sponsor of sports. Corporate sponsorship of sporting events mainly in exchange for title, advertising, patents and write-off of business returns, to expand and strengthen the target audience communication, and enhance their brand awareness, reputation. So as to achieve mutual benefit and win-win situation.

\section{B. An Analysis of the Factors Affecting the Development of futsal football in Ganzhou City}

\section{1) Competition venues and facilities factors}

Because the five-person football in Ganzhou city development time is shorter, many aspects still not perfect, Competition venues and facilities are also seriously inadequate, and this is an important factor restricting the development of futsal. But with the government departments in recent years to carry out the importance of mass sports, in recent years, although a few new football field, but still cannot meet the growing needs of football lovers. The utilization of football venues is low, another important factor is the lack of open space leading to slow development of futsal, such as artillery soccer sites at all levels of school, are of comparable quality in all soccer fields. However, due to the school's opening few concerns, there are some venues open to the outside world, but the higher rental costs.

\section{2) Social sports management system factors}

Social Sports Management System refers to the division of responsibilities in the regulation of social sports of national jurisdiction, organizational structure, can only 
configure the operation mode, the sum of the operating mechanisms. The Development of Football System in Ganzhou City, and the degree of attention the local government sector are inextricably linked, state and Government should pay attention to mass sports, but currently in Ganzhou Urban Area football management pay more attention to the eleven-a-side football tournament and development, futsal generally considered only simplify amusement games eleven - Football, this in itself is a wrong idea.

\section{3) Participants' own objective factors}

In the survey of Ganzhou urban futsal football participants found, factors affecting the objective conditions of participants involved in the movement of Futsal, support families, hobbies, as well as the top three factors spare time. Overall, Many families of five-player soccer players are still more supportive of football. A small number of opposing attitudes are mostly in school high school students, parents thought to be involved in addition to a football game with a certain degree of risk, also need to occupy a part of the learning time. Affect their child's academic performance. Participants' interest in football, the main factor in free time outside of work and learning also affect the participants take part in sports.

\section{DISCUSSIONS AND CONCLUSION}

\section{A. Conclusions}

1) Compared to other sports, five people football less investment, easy to carry out the masses, interesting and ornamental High, suitable for many people involved, very suitable for carrying out in Ganzhou city. The increase in the number of five-a-side soccer teams and the enthusiasm of the masses are bound to play a positive role in the national fitness campaign. At present, Ganzhou city five people football participation in the community higher education, age is younger, and have a certain physical fitness and sports spending power, sports demand is also more intense.

2) Some parts of the Ganzhou urban area have not been effectively used, there are fewer soccer venues available. Ganzhou City Football Association organized the referee team number shortage, the low level of law enforcement referee. The team did not have the guidance of professional and technical personnel, in this issue will also cause the enthusiasm of the participants to reduce.

3) At present, Ganzhou urban five-party football campaign is not high propaganda, and people's attention is not enough.

\section{B. Recommendations}

1) Hope that the relevant functional departments can vigorously promote and promote the five-a-side football, aware of the importance of exercise to improve the health of the masses and the quality of life, for the development of the five-a-side football to give the appropriate support and preferential policies. The Futsal movement to communities, and organize the competition between the various communities, attract more football talent, grow Ganzhou Urban Area futsal team, expand the size of the team, and then cultivate the quality of the five-a-side football team.

2) Improve the utilization of existing football venues, of undeveloped but can be used for site development and utilization of local building using reasonable, and improve the quality of service in private football venues, to develop a reasonable fee. Perfecting Ganzhou City Football Club Mechanism, Improve the hardware and software equipment.

3) More domestic well-known five-a-side football referee and coaches to Ganzhou urban teaching training, improve the level of existing referee law enforcement and coaches' professional guidance.

\section{REFERENCES}

[1] Quan Shulin. Fu Hongli.Analysis on the Factors Affecting the Development Level of the Five-player Soccer in Colleges and Universities in Zhengzhou [J].Henan Agriculture 2015.

[2] Lin Nannan.Research on the Present Situation and Countermeasures of the Five - player Football in China[J].Jilin Teachers Institute of Engineering and Technology 2011.

[3] Gao Bo.Five-person Football in the school-based sports culture in the development [J].Electronic production. 2014.

[4] Xia Qing.Chen Yunlong.Analysis on the Characteristics and Significance of Campus Futsal [J].Chinese school sports (higher education). 2015.

[5] Wang Hongfei.Research on the Five-player Football Teaching of College Students in Colleges and Universities [J].Sports World (Academic Edition). 2016

[6] Qing Chenpin.Xia Qing.Huang Jiayong.Research on the Present Situation and Countermeasure of the Five-aided Football League in China [J].Chinese school sports (Higher Education) 2015

[7] Zhang Fan.Liu Rong.A New Way to Develop Soccer in Colleges and Universities - Futsal Football [J].Journal of Beijing Sport University.2000.02

[8] Yan Hongjie.On the five-a-side football [J].Journal of Nanjing Institute of Physical Education (Social Science Edition).2004.05

[9] Ke Shangshang.Bai Fuchuang.On the characteristics and value of the five-a-side football [J].Journal of Gansu Lianhe University (Natural Science Edition).2008.05

[10] Sun Haifeng.Cong Rihui.Analysis on the Development Prospect of Futsal Football in Daqing Area [J].Journal of Jilin Technical Teachers College.2009.05 